\title{
STUDI SIFAT FISIK, KIMIA, FUNGSIONAL, DAN KADAR ASAM SIANIDA TEPUNG KECAMBAH KACANG KORO PEDANG (Canavalia ensiformis L.)
}

\author{
Study of Physical, Chemical, Functional Properties, and Hydrogen Cyanide Content of Jack Bean
} Sprout (Canavalia ensiformis L.) Flour.

\author{
I Dewa Ayu Bintang Damayanti ${ }^{1)}$, Ni Wayan Wisaniyasa ${ }^{2)}$, I Wayan Rai Widarta ${ }^{2)}$ \\ ${ }^{1}$ Mahasiswa Program Studi Imu dan Teknologi Pangan, Fakultas Teknologi Pertanian, Unud \\ ${ }^{2}$ Dosen Program Studi Imu dan Teknologi Pangan, Fakultas Teknologi Pertanian, Unud \\ PS Ilmu dan Teknologi Pangan, Fakultas Teknologi Pertanian, Universitas Udayana, \\ Kampus Bukit Jimbaran, Badung-Bali
}

\begin{abstract}
The purpose of this research was to determine the physical, chemical, functional properties, and hydrogen cyanide content of jack bean sprout (Canavalia ensiformis L.) flour. This research used two treatments that was without germination and 48 hours of germination. The treatments were repeated three times resulting in six units of experiments. Jack bean flour and jack bean sprout flour were analyzed by paired T-test. The results showed that the germination of jackbean had a very significant effect on the decrease of oil absorption from $1.59 \mathrm{mg} / \mathrm{l}$ to $0.79 \mathrm{mg} / \mathrm{l}$. The treatment had a significant effect on the increase of water content from $11.10 \%$ to $11.77 \%$; increase of protein content from $28.52 \%$ to $29.18 \%$; decrease of fat content from $6.33 \%$ to $5.54 \%$; decrease of carbohydrate content from $51.19 \%$ to $50.77 \%$; increase of crude fiber content from $11.69 \%$ to $12.30 \%$; increase of water holding capacity from $1.42 \mathrm{ml} / \mathrm{g}$ to $1.58 \mathrm{ml} / \mathrm{g}$; decrease of swelling volume from $8.97 \mathrm{ml} / \mathrm{g}$ to $8.31 \mathrm{ml} / \mathrm{g}$; increase of solubility from $0.06 \%$ to $0.07 \%$; and decrease of hydrogen cyanide content from $14.13 \mathrm{mg} / \mathrm{kg}$ to $11.00 \mathrm{mg} / \mathrm{kg}$. This research had no effect on bulk density and ash content.
\end{abstract}

Keywords : hydrogen cyanide; jackbean sprout flour; chemical, functional and physical properties

\section{PENDAHULUAN}

Kacang-kacangan merupakan sumber protein yang penting dalam upaya perbaikan gizi. Hal tersebut disebabkan kandungan protein yang cukup tinggi, pengadaannya mudah dan relatif murah harganya dibandingkan dengan sumber protein hewani seperti daging dan susu (Utomo dan Antarlina, 1998). Indonesia banyak memiliki potensi kacang-kacangan, salah satunya kacang koro pedang. Tanaman kacang koro pedang (Canavalia ensiformis L.) merupakan tanaman kacang polong yang sangat potensial

\footnotetext{
*Korespondensi Penulis:

E-mail: bintangdamayanti19@gmail.com ${ }^{1)}$
}

dikembangkan sebagai komoditi alternatif pendamping kedelai, untuk pembuatan tempe, tahu, kecap, dan susu nabati. Hal ini karena kandungan gizi koro pedang tidak kalah dengan kacang kedelai, yaitu protein $27,4 \%$ sedangkan kedelai 39\%, kandungan karbohidratnya sebesar $63,5 \%$ sementara kedelai hanya 35,5\% (Usman dkk., 2013).

Kacang koro pedang memiliki potensi yang baik untuk dikembangkan, namun memiliki kelemahan karena mengandung senyawa antigizi berupa asam sianida. Biji kacang koro pedang tidak dapat dimakan secara langsung karena adanya kandungan asam sianida $(\mathrm{HCN})$ cukup tinggi dan sangat 
berbahaya apabila masuk ke dalam tubuh manusia. Menurut Akpapunam dan Dedeh (1997) kandungan HCN pada kacang koro pedang mentah mencapai $11,2 \mathrm{mg} / 100 \mathrm{~g}$ berat kering atau 112 ppm. Kandungan HCN pada bahan mentah kacang koro pedang tergolong tinggi, sedangkan batas aman mengkonsumsi bahan pangan adalah kurang dari $50 \mathrm{ppm}$ (Winarno, 1992). Oleh sebab itu diperlukan adanya sebuah proses pengolahan yang dapat mengurangi jumlah komponen HCN sehingga aman dikonsumsi. Salah satu pengolahan kacang-kacangan yang banyak dilakukan di Indonesia yaitu perkecambahan (Anita, 2009).

Perkecambahan telah dikenal sebagai proses pengolahan yang tidak mahal dan teknologi yang efektif dalam meningkatkan kualitas kacang-kacangan dan menurunkan jumlah komponen antinutrisi sehingga membuat kecambah aman untuk dikonsumsi. Hal tersebut juga sesuai dengan hasil penelitian Wisaniyasa dkk., (2015) bahwa perkecambahan selama 48 jam dapat memperbaiki kandungan nutrisi dan sifat fungsional dari tepung kecambah kacang gude.

Akpapunam dan Dedeh (1997) menyatakan bahwa perlakuan perkecambahan pada kacang koro pedang lebih efektif menurunkan zat antinutrisi daripada perebusan. Perkecambahan kacang koro pedang selama 72 jam berhasil menurunkan kadar HCN pada tepung kecambah yang dihasilkan sebesar 49,1\%. Berdasarkan pra penelitian bahwa perkecambahan kacang koro selama 72 jam menyebabkan kacang telah memiliki kecambah yang terlalu panjang dan juga radikel telah ditumbuhi akar-akar halus. Menurut Anita (2009), apabila selama perkecambahan telah tumbuh akar-akar halus pada radikel, maka secara sensoris kecambah tidak layak untuk dimakan. Maka dari itu, penelitian ini menggunakan waktu perkecambahan yang lebih singkat yaitu 48 jam.
Kecambah perlu diolah menjadi produk setengah jadi yaitu tepung agar memiliki masa simpan yang lebih lama, mudah diaplikasikan pada produk pangan, serta membutuhkan ruang lebih sedikit selama penyimpanan. Tepung perlu diketahui sifat fisik, sifat kimia maupun fungsionalnya untuk mempermudah cara pengolahan, penyimpanan maupun mengetahui kandungan gizinya (Wisaniyasa dan Suter, 2016). Berdasarkan latar belakang tersebut, maka perlu dilakukan penelitian untuk mengetahui sifat fisik, kimia, fungsional, dan kadar $\mathrm{HCN}$ pada tepung kecambah kacang koro pedang.

\section{METODE PENELITIAN}

\section{Tempat dan Waktu}

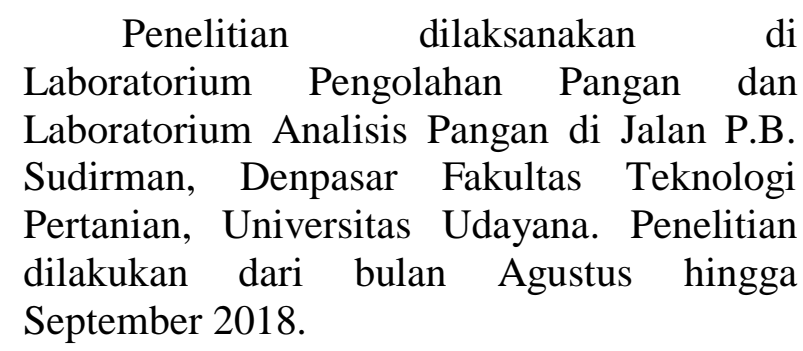

\section{Bahan dan Alat}

Bahan utama adalah kacang koro pedang putih kering. Bahan kimia adalah aquades, asam sulfat $\left(\mathrm{H}_{2} \mathrm{SO}_{4}\right)$, minyak kedelai, natrium hidroksida $(\mathrm{NaOH})$, asam klorida $(\mathrm{HCl})$, tablet Kjeldahl, heksan, phenolphtalin (PP), alkohol 96\%, asam borat, amonium hidroksida $\left(\mathrm{NH}_{4} \mathrm{OH}\right)$, kalium iodida $(\mathrm{KI})$, dan perak nitrat $\left(\mathrm{AgNO}_{3}\right)$.

Alat yang digunakan adalah wadah plastik, blender (Phillips), waskom, timbangan analitik(Shimadzu), oven (Exocell), kertas saring, kertas whatman 42, ayakan 60 mesh, Erlenmeyer (Pyrex), cawan porselin, sentrifuge (Centurion Scientific), vortex (Maxi Mix II), eksikator, corong, pipet tetes, hot plate, labu takar, buret, muffle, destilator, spatula, pemanas listrik, tabung sentrifuse, gelas ukur (Pyrex), tabung reaksi 
(Pyrex), gelas beker (Pyrex), pipet volume, labu kjeldahl, soxhlet, dan waterbath.

\section{Rancangan Percobaan}

Metode percobaan yang dilakukan secara eksperimen dengan perlakuan tanpa perkecambahan $(\mathrm{T})$ dan perkecambahan selama 48 jam (K). Perlakuan diulang sebanyak 3 kali sehingga diperoleh 6 unit percobaan. Perbedaan sifat fisik, kimia, fungsional, dan kadar asam sianida diuji dengan uji $\mathrm{T}$ berpasangan (Steel and Torrie, 1995).

\section{Pelaksanaan Penelitian}

Tahap 1 pembuatan tepung kacang koro pedang yaitu sebanyak 150 gram kacang koro pedang yang sudah disortasi, lalu direndam menggunakan air hangat $50^{\circ} \mathrm{C}$ (kacang : air = 1:3) selama 36 jam dan air rendaman diganti setiap 6 jam. Kacang koro ditiriskan, lalu dikeringkan menggunakan oven dengan suhu $50^{\circ} \mathrm{C}$ selama 24 jam, dihaluskan dengan blender dan diayak menggunakan ayakan 60 mesh (Wisaniyasa dkk., 2015 yang dimodifikasi). Tahap 2 pembuatan tepung kecambah kacang koro pedang yaitu sebanyak 150 gram kacang koro pedang yang sudah disortasi, direndam menggunakan air hangat $50^{\circ} \mathrm{C}$ (kacang : air $=1: 3$ ) selama 36 jam dan air rendaman diganti setiap 6 jam. Selanjutnya ditiriskan, lalu ditempatkan pada wadah plastik yang bagian dalam sudah dilapisi daun pisang dan ditutupi dengan daun pisang pada bagian atas. Kacang koro diberi perlakuan perkecambahan selama 48 jam dan setiap 12 jam diberi percikan air sebanyak $10 \mathrm{ml}$. Kecambah kacang koro pedang dikeringkan menggunakan oven dengan suhu $50^{\circ} \mathrm{C}$ selama 24 jam, dihaluskan dengan blender dan diayak menggunakan ayakan 60 mesh.

\section{Variabel yang Diamati}

Variabel yang diamati yaitu sifat fisik meliputi densitas kamba (Muchtadi dkk., (1993) dalam Anita, 2009), sifat kimia meliputi kadar air, kadar lemak (AOAC, 1995 kadar abu, kadar protein, kadar karbohidrat, dan kadar serat kasar (Sudarmadji dkk.,1997), sifat fungsional meliputi daya serap air (Lin dkk. 1974), daya serap minyak (Soluski dan Fleming (1977) dalam Budijanto dkk., 2011), swelling volume, kelarutan (Collado dan Corke, 1999) dan kadar asam sianida (Sudarmadji dkk.,1997).

\section{HASIL DAN PEMBAHASAN}

\section{Sifat Fisik Tepung Kacang Koro Pedang dan Tepung Kecambah Kacang Koro Pedang}

Proses perkecambahan berpengaruh tidak nyata terhadap sifat fisik yaitu densitas kamba. Hasil analisis densitas kamba tepung kacang koro pedang dan tepung kecambah kacang koro pedang dapat dilihat pada Tabel 1.

Tabel 1. Hasil Analisis Sifat Fisik Tepung Kacang Koro Pedang dan Tepung Kecambah Kacang Koro Pedang

\begin{tabular}{lccc}
\hline Parameter & $\begin{array}{c}\text { Tepung } \\
\text { Kacang } \\
\text { Koro Pedang }\end{array}$ & $\begin{array}{c}\text { Tepung } \\
\text { Kecambah } \\
\text { Kacang } \\
\text { Koro } \\
\text { Pedang }\end{array}$ & $\begin{array}{c}\text { Hasil } \\
\text { T-test }\end{array}$ \\
\hline $\begin{array}{l}\text { Densitas } \\
\text { Kamba } \\
(\mathrm{g} / \mathrm{ml})\end{array}$ & $0,53 \pm 0,008$ & $0,54 \pm 0,001$ & $\mathrm{~ns}$ \\
\hline
\end{tabular}

Ket : $\mathrm{ns}=$ non signifikan

$\begin{array}{cccc}\text { Hasil analisis pada Tabel } 1 \\ \text { menunjukkan } & \text { bahwa } & \text { perkecambahan }\end{array}$ berpengaruh tidak nyata $(\mathrm{P}>0,05)$ terhadap densitas kamba tepung kecambah kacang koro pedang. Tabel 1 menunjukkan bahwa densitas kamba tepung kacang koro pedang 0,53 g/ml, sedangkan densitas kamba tepung kecambah kacang koro pedang 0,54 g/ml. Densitas kamba dipengaruhi oleh ukuran bahan dimana ukuran bahan akan mempengaruhi porositas (Julita, 2012). Tepung kacang koro pedang dan tepung kecambah kacang koro pedang 
dihasilkan dari proses pengayakan dengan ukuran yang sama yaitu 60 mesh sehingga tidak mempengaruhi densitas kamba yang dihasilkan. Hal ini sesuai dengan penelitian Anita (2009) yang menyatakan bahwa perkecambahan tidak memberi pengaruh yang signifikan terhadap nilai densitas kamba kacang komak.

\section{Sifat Kimia Tepung Kacang Koro Pedang dan Tepung Kecambah Kacang Koro Pedang}

Perlakuan perkecambahan berpengaruh nyata terhadap kadar air, kadar protein, kadar lemak, kadar karbohidrat, dan kadar serat kasar, namun tidak berpengaruh nyata terhadap kadar abu. Data penelitian sifat kimia tepung kacang koro pedang dan tepung kecambah kacang koro pedang dapat dilihat pada Tabel 2.

Tabel 2. Hasil Analisis Kimia Tepung Kacang Koro Pedang dan Tepung Kecambah Kacang Koro Pedang

\begin{tabular}{cccc}
\hline Parameter & $\begin{array}{c}\text { Tepung } \\
\text { Kacang } \\
\text { Koro } \\
\text { Pedang }\end{array}$ & $\begin{array}{c}\text { Tepung } \\
\text { Kecambah } \\
\text { Kacang } \\
\text { Koro } \\
\text { Pedang }\end{array}$ & $\begin{array}{c}\text { Hasil } \\
\text { T-test }\end{array}$ \\
\hline $\begin{array}{c}\text { Kadar Air } \\
(\%)\end{array}$ & $11,10 \pm 0,49$ & $11,77 \pm 0,14$ & $*$ \\
$\begin{array}{c}\text { Kadar Abu } \\
(\%)\end{array}$ & $2,86 \pm 0,07$ & $2,74 \pm 0,04$ & $n s$ \\
$\begin{array}{c}\text { Kadar } \\
\text { Protein }(\%) \\
\text { Kadar } \\
\text { Lemak }(\%) \\
\text { Kadar }\end{array}$ & $28,52 \pm 0,13$ & $29,18 \pm 0,22$ & $*$ \\
$\begin{array}{c}\text { Karbohidrat } \\
(\%)\end{array}$ & $51,19 \pm 0,15$ & $50,77 \pm 0,14$ & $*$ \\
$\begin{array}{c}\text { Kadar Serat } \\
\text { Kasar }(\%)\end{array}$ & $11,69 \pm 0,15$ & $12,30 \pm 0,06$ & $*$ \\
\hline
\end{tabular}

Ket : ns= non signifikan

*) berpengaruh nyata

\section{Kadar Air}

Perkecambahan berpengaruh nyata $(\mathrm{P}<0,05)$ terhadap kadar air tepung kecambah kacang koro pedang. Tabel 2 menunjukkan bahwa kadar air tepung kacang koro pedang sebesar $11,10 \%$ dan tepung kecambah kacang koro pedang sebesar $11,77 \%$. Hal ini disebabkan karena kacang koro pedang yang dikecambahkan diberikan percikan air setiap 12 jam sekali sehingga terjadi penyerapan air selama perkecambahan. Menurut Mares dkk., (2017) bahwa semakin lama waktu perkecambahan pada wijen, maka semakin banyak air yang terserap ke dalam biji. Anggrahini (2007) menyatakan pula bahwa terjadi peningkatan kadar air secara signifikan pada kecambah kacang hijau yang diinkubasi mulai 0 hingga 48 jam. Hal tersebut juga dilaporkan oleh Kavitha dan Parimalavalli (2014) bahwa selama perkecambahan, biji menyerap air dari lingkungan sekitar untuk metabolisme sehingga kadar air menjadi meningkat. Semakin lama perkecambahan, maka semakin meningkat kadar air sebab terjadi hidrasi pada sel di dalam biji.

\section{Kadar Abu}

Perkecambahan berpengaruh tidak nyata $(\mathrm{P}>0,05)$ terhadap kadar abu tepung kecambah kacang koro pedang. Tabel 2 menunjukkan bahwa kadar abu tepung kacang koro pedang sebesar 2,86\% sedangkan tepung kecambah kacang koro pedang 2,74\%. Perlakuan pencucian dan perendaman sebelum germinasi dapat mempengaruhi kadar abu. Hal ini dapat disebabkan oleh kehilangan mineral larut air (Anita, 2009). Perlakuan pendahuluan pencucian dan perendaman yang dilakukan pada tepung kacang koro pedang dan tepung kecambah kacang koro pedang adalah sama yaitu selama 36 jam sehingga tidak terjadi perubahan yang signifikan pada kadar abu kedua tepung tersebut.

\section{Kadar Protein}

Perkecambahan berpengaruh nyata $(\mathrm{P}<0,05)$ terhadap kadar protein tepung kecambah kacang koro pedang. Tabel 2 menyatakan bahwa kadar protein tepung 
kacang koro pedang sebesar 28,52\%, sedangkan tepung kecambah kacang koro pedang sebesar 29,18\%. Menurut Lopez dan Escobedo (1989) bahwa perkecambahan dapat meningkatkan kandungan protein sebab terjadi pembentukan asam-asam amino essensial yang merupakan penyusun protein yang diperlukan selama pertumbuhan kecambah. Selain itu menurut Anggrahini (2007) bahwa selama perkecambahan akan terjadi peningkatan jumlah enzim lipase dan amilase yang digunakan untuk mendegradasi lemak dan karbohidrat menjadi komponen metabolik yang dibutuhkan selama terjadi perkecambahan. Enzim merupakan komponen dari protein sehingga bila terjadi peningkatan jumlah enzim selama perkecambahan, maka kadar protein juga akan meningkat.

\section{Kadar Lemak}

Perkecambahan berpengaruh nyata $(\mathrm{P}<0,05)$ terhadap kadar lemak tepung kecambah kacang koro pedang. Tabel 2 menunjukkan kadar lemak tepung kacang koro pedang sebesar $6,33 \%$ dan tepung kecambah kacang koro pedang sebesar 5,54\%. Kadar lemak tepung kecambah kacang koro lebih rendah dibandingkan tepung kacang koro pedang karena lemak diubah menjadi energi selama proses perkecambahan.

Menurut Sadjad (1974) dalam Anita (2009), selama perkecambahan kandungan lemak menurun karena lemak sebagai cadangan makanan dihidrolisis dan akan masuk ke jalur glikolisis untuk menghasilkan energi perkecambahan. Hal ini sesuai dengan penelitian Anggrahini (2007) bahwa selama perkecambahan terjadi penurunan kandungan lemak dan terjadi peningkatan jumlah enzim lipase. Hasil penelitian Astawan dan Hazmi (2016) menyatakan bahwa perkecambahan dapat menurunkan kadar lemak pada tepung kecambah kacang kedelai.

\section{Kadar Karbohidrat}

Perkecambahan berpengaruh nyata $(\mathrm{P}<0,05)$ terhadap kadar karbohidrat tepung kecambah kacang koro pedang. Kadar karbohirat tepung kacang koro pedang lebih tinggi daripada tepung kecambah kacang koro pedang yaitu $51,19 \%$. Nilai tepung kecambah kacang koro pedang pada Tabel 2 sebesar 50,77\%. Menurut Osman (2007) adanya penurunan nilai kadar karbohidrat pada saat perkecambahan dapat disebabkan karena karbohidrat dijadikan sebagai sumber energi pada saat perkecambahan biji.

Anggrahini (2007).melaporkan bahwa kadar karbohidrat kecambah kacang hijau makin berkurang seiring makin lamanya waktu perkecambahan. Selama perkecambahan terjadi hidrolisis karbohidrat menjadi senyawa yang lebih sederhana guna pertumbuhan embrio. Karbohidrat sebagai bahan persediaan makanan didegradasi oleh enzim $\alpha$-amilase dan $\beta$-amilase. Enzim $\alpha$ amilase akan mendegradasi pati menjadi glukosa dan dekstrin, sedangkan $\beta$ - amilase memecah pati menjadi maltosa dan dekstrin, kemudian didegradasi kembali untuk menghasilkan energi.

\section{Kadar Serat Kasar}

Perkecambahan berpengaruh nyata $(\mathrm{P}<0,05)$ terhadap kadar serat kasar tepung kecambah kacang koro pedang. Tabel 2 menunjukan bahwa nilai kadar serat kasar tepung kecambah kacang koro pedang lebih besar yaitu 12,30\% daripada tepung kacang koro pedang yaitu sebesar $11,69 \%$. Menurut Lombu (2017) bahwa perkecambahan berpengaruh sangat nyata terhadap serat kasar tepung kecambah jagung. Rumiyati dkk., (2012) menyatakan bahwa perkecambahan hingga 9 hari mampu meningkatkan kadar serat kasar pada biji Australian Sweet Lupin. Peningkatan kadar serat kasar terjadi karena perubahan polisakarida yang ada pada dinding sel, seperti selulosa, glukosa dan manosa. Blessing dan Gregory (2010) melaporkan 
bahwa selama perkecambahan terjadi penurunan pati dan sintesis selulosa serta hemiselulosa sehingga kadar serat kasar meningkat.

\section{Sifat Fungsional Tepung Kacang Koro Pedang dan Tepung Kecambah Kacang Koro Pedang \\ Perkecambahan berpengaruh sangat nyata terhadap daya serap minyak, berpengaruh nyata terhadap daya serap air, swelling volume, dan kelarutan. Data sifat fungsional yang meliputi daya serap air, daya serap minyak, swelling volume, dan kelarutan tepung kacang koro pedang dan tepung kecambah kacang koro pedang dapat dilihat pada Tabel 3. \\ Tabel 3. Hasil Analisis Sifat Fungsional Tepung Kacang Koro Pedang dan Tepung Kecambah Kacang Koro Pedang}

\begin{tabular}{cccc}
\hline Parameter & $\begin{array}{c}\text { Tepung } \\
\text { Kacang } \\
\text { Koro } \\
\text { Pedang }\end{array}$ & $\begin{array}{c}\text { Tepung } \\
\text { Kecambah } \\
\text { Koro } \\
\text { Pedang }\end{array}$ & $\begin{array}{c}\text { Hasil } \\
\text { T-test }\end{array}$ \\
\hline $\begin{array}{c}\text { Daya } \\
\text { Serap Air } \\
\text { (ml/g) }\end{array}$ & $1,42 \pm 0,05$ & $1,58 \pm 0,001$ & $*$ \\
$\begin{array}{c}\text { Daya } \\
\text { Serap } \\
\text { Minyak } \\
\text { (ml/g) }\end{array}$ & $1,59 \pm 0,006$ & $0,79 \pm 0,003$ & $* *$ \\
$\begin{array}{c}\text { Swelling } \\
\text { Volume } \\
\text { (ml/g) }\end{array}$ & $8,97 \pm 0,31$ & $8,31 \pm 0,12$ & $*$ \\
$\begin{array}{c}\text { Kelarutan } \\
(\%)\end{array}$ & $0,06 \pm 0,001$ & $0,07 \pm 0,004$ & $*$ \\
\hline Ket: & & & \\
\hline
\end{tabular}

Ket : *) berpengaruh nyata

**) berpengaruh sangat nyata

\section{Daya Serap Air}

Perkecambahan berpengaruh nyata $(\mathrm{P}<0,05)$ terhadap daya serap air tepung kecambah kacang koro pedang. Tabel 3 menunjukkan daya serap air tepung kacang koro pedang sebesar $1,42 \mathrm{ml} / \mathrm{g}$ sedangkan tepung kecambah kacang koro pedang sebesar $1,58 \mathrm{ml} / \mathrm{g}$. Daya serap air mempengaruhi kemudahan dalam penghomogenan adonan tepung ketika dicampur dengan air. Tepung yang memiliki daya serap air yang tinggi cenderung lebih cepat dihomogenkan (Aini dkk., 2016). Peningkatan daya serap air dapat disebabkan oleh produksi senyawa yang mempunyai kapasitas menahan air yang baik seperti gula terlarut pada tepung yang dikecambahkan (Ocheme, dkk. 2015; Oluwalana, 2014).

Daya serap air juga dapat meningkat akibat meningkatnya kadar protein pada tepung kecambah kacang koro pedang. Menurut Astawan dan Hazmi (2016), kemampuan bahan pangan untuk mengikat air tidak terlepas dari keterlibatan dari komponen penyusun seperti protein. Kemampuan protein untuk mengikat air disebabkan adanya gugus yang bersifat hidrofilik (mudah menyerap air). Menurut Wisaniyasa dkk. (2015), kacang gude yang dikecambahkan hingga 48 jam dapat meningkatkan daya serap air yang dapat disebabkan peningkatan kadar protein. Penelitian ini juga menunjukkan bahwa tepung kecambah kacang koro pedang mengalami peningkatan kadar protein selama perkecambahan.

\section{Daya Serap Minyak}

Perkecambahan berpengaruh sangat nyata $(\mathrm{P}<0,01)$ terhadap daya serap minyak tepung kecambah kacang koro pedang. Tabel 3 menunjukkan daya serap minyak tepung kacang koro pedang sebesar 1,59 ml/g, sedangkan tepung kecambah kacang koro pedang sebesar $0,79 \mathrm{ml} / \mathrm{g}$. Daya serap minyak berkaitan dengan kandungan protein dalam bahan. Protein memiliki sisi non polar yang dapat berinteraksi dengan lemak. Banyaknya sisi protein yang bersifat hidrofobik dan protein tidak larut air dalam bahan mengakibatkan peningkatan kapasitas penyerapan minyak (Zayas, 1997). Berdasarkan hasil penelitian, proses perkecambahan kacang koro pedang mengakibatkan penurunan daya serap minyak. 
Hal tersebut dapat disebabkan oleh protein yang terkandung dalam tepung kecambah kacang koro pedang memiliki sisi hidrofilik yang lebih banyak dibandingkan sisi hidrofobik sehingga daya serap air meningkat dan daya serap minyak menurun.

\section{Swelling Volume}

Perkecambahan berpengaruh nyata $(\mathrm{P}<0,05)$ terhadap swelling volume tepung kecambah kacang koro pedang. Tabel 3 menunjukkan swelling volume tepung kacang koro pedang sebesar $8,97 \mathrm{ml} / \mathrm{g}$, sedangkan tepung kecambah kacang koro pedang sebesar $8,31 \mathrm{ml} / \mathrm{g}$. Hal tersebut kemungkinan disebabkan karena pati yang terdapat pada tepung kecambah telah mengalami dekstrinasi sehingga tidak dapat mengembang dengan maksimal. Oluwalana (2014) menyatakan bahwa tepung jagung mentah memiliki kandungan karbohidrat yang belum mengalami dektrinasi sehingga memiliki swelling volume yang lebih tinggi daripada tepung kecambah. Pembengkakan terjadi karena putusnya ikatan hidrogen intermolekul sehingga air masuk ke dalam granula dan mengakibatkan pembengkakan granula.

\section{Kelarutan}

Perkecambahan berpengaruh nyata $(\mathrm{P}<0,05)$ terhadap kelarutan tepung kecambah kacang koro pedang. Tabel 3 menunjukkan bahwa kelarutan tepung kacang koro pedang sebesar $0,06 \%$, sedangkan tepung kecambah kacang koro pedang sebesar $0,07 \%$. Kelarutan menunjukkan seberapa banyak tepung yang dapat terlarut di dalam air. Molekul yang relatif lebih kecil inilah yang mudah larut dalam air. Oluwalana (2014) melaporkan bahwa selama proses perkecambahan, aktivitas alfa amilase mengalami peningkatan. Enzim ini menghidrolisis amilosa dan amilopektin menjadi dektrin dan maltose. Peningkatan jumlah gula yang larut ini mengakibatkan peningkatan kelarutan.
Hasil penelitian serupa juga dilaporkan oleh Elvira (2018) bahwa tepung kecambah kacang tunggak memiliki nilai kelarutan lebih tinggi dari pada tepung kacang tunggak karena hidrolisis karbohidrat menyebabkan molekul pati terurai menjadi senyawa yang lebih sederhana seperti glukosa yang lebih mudah larut dalam air dibandingkan pati.

\section{Kadar Asam Sianida Tepung Kacang}

\section{Koro Pedang dan Tepung Kecambah Kacang Koro Pedang}

Perkecambahan berpengaruh nyata terhadap kadar asam sianida. Hasil analisis kadar asam sianida tepung kacang koro pedang dan tepung kecambah kacang koro pedang dapat dilihat pada Tabel 4 .

Tabel 4. Hasil Analisis Sifat Fungsional dan Kadar Asam Sianida Tepung Kacang Koro Pedang dan Tepung Kecambah Kacang Koro Pedang

\begin{tabular}{cccc}
\hline Parameter & $\begin{array}{c}\text { Tepung } \\
\text { Kacang } \\
\text { Koro } \\
\text { Pedang }\end{array}$ & $\begin{array}{c}\text { Tepung } \\
\text { Kecambah } \\
\text { Koro Pedang }\end{array}$ & $\begin{array}{c}\text { Hasil } \\
\text { T-test }\end{array}$ \\
\hline $\begin{array}{c}\text { Kadar Asam } \\
\text { Sianida } \\
(\mathrm{mg} / \mathrm{kg})\end{array}$ & $14,13 \pm 0,62$ & $11,00 \pm 0,45$ & $*$ \\
\hline
\end{tabular}

Ket $: *)$ berpengaruh nyata

Perkecambahan berpengaruh nyata $(\mathrm{P}<0,05)$ terhadap kadar asam sianida tepung kecambah kacang koro pedang. Berdasarkan Tabel 4 kadar asam sianida tepung kacang koro pedang sebesar $14,13 \mathrm{mg} / \mathrm{kg}$, sedangkan pada tepung kecambah kacang koro pedang sebesar $11,00 \mathrm{mg} / \mathrm{kg}$. Hal tersebut menunjukkan bahwa perkecambahan selama 48 jam mampu menurunkan kadar asam sianida pada tepung kecambah kacang koro pedang sebanyak 22,2\% sehingga sudah aman untuk dikonsumsi. Akpapunam dan Dedeh (1997) juga menyatakan bahwa perkecambahan selama 72 jam mampu menurunkan kadar asam sianida sebesar 
49,1\% dari kadar asam sianida pada kacang koro pedang mentah.

Dibofori dkk. (1994) menyatakan bahwa semakin lama waktu perkecambahan, maka kadar HCN menjadi semakin menurun karena adanya enzim hidrolitik yaitu $\beta$ glusidase. Enzim tersebut menghidrolisis glukosida sianogenik menjadi cyanohydrins dan selanjutnya menjadi komponen sianida bebas. Sianida bebas akan hilang karena translokasi ke bagian-bagian lainnya seperti akar, tunas, atau daun.

\section{KESIMPULAN DAN SARAN}

\section{Kesimpulan}

Berdasarkan hasil penelitian dapat disimpulkan bahwa:

1. Perkecambahan kacang koro pedang berpengaruh sangat nyata terhadap daya serap minyak, berpengaruh nyata terhadap kadar air, kadar protein, kadar lemak, kadar karbohidrat, kadar serat kasar, daya serap air, swelling volume, kelarutan, dan kadar asam sianida.

2. Tepung kecambah kacang koro pedang mempunyai sifat fisik yaitu densitas kamba $0,54 \mathrm{~g} / \mathrm{ml}$, sifat kimia yaitu kadar air $11,77 \%$, kadar abu 2,74\%, kadar protein $29,18 \%$, kadar lemak 5,54\%, kadar karbohidrat $50,77 \%$, kadar serat kasar $12,30 \%$, serta sifat fungsional yaitu daya serap air $1,58 \mathrm{ml} / \mathrm{g}$, daya serap minyak $0,79 \mathrm{ml} / \mathrm{g}$, swelling volume $8,31 \mathrm{ml} / \mathrm{g}$, kelarutan $0,07 \%$ dan kadar asam sianida $11,00 \mathrm{mg} / \mathrm{kg}$.

\section{Saran}

Berdasarkan hasil penelitian, maka dapat disarankan hal-hal sebagai berikut:

1. Perkecambahan selama 48 jam dapat dilakukan untuk meningkatkan kualitas kacang koro pedang.

2. Perlu dilakukan kajian lebih lanjut terkait masa simpan tepung kecambah kacang koro pedang serta aplikasinya pada produk olahan pangan.

\section{DAFTAR PUSTAKA}

Aini, N., G. Wijonarko, dan B. Sustriawan. 2016. Sifat fisik, kimia dan fungsional tepung jagung yang diproses melalui fermentasi. Agritech, 36: 160-169.

Akpapunam, M.A. dan S. S. Dedeh. 1997. Some physicochemical properties and anti-nutritional factors or raw, cooked and germinated jack bean (Canavalia ensiformis). Food Chemistry 59(1): 121-125.

Anggrahini, S. 2007. Pengaruh lama pengecambahan terhadap kandungan $\alpha$ tokoferol dan senyawa proksimat kecambah kacang hijau (Phaseolus radiates L.). Agritech. 27: 152-157.

Anita, S. 2009. Studi Sifat Fisikokimia Sifat Fungsional Karbohidrat Dan Aktivitas Antioksidan Tepung Kecambah Kacang Komak (Lablab purpureus (L) sweet) [skripsi]. Tidak dipublikasikan. Institut Pertanian Bogor, Bogor.

AOAC. 1995. Official Methods of Analysis of The Association of Official Analytical Chemistry. Washington DC: AOAC Int.

Astawan, M. dan K. Hazmi. 2016. Karakteristik fisikokimia tepung kecambah kedelai. Pangan 25: 105-112.

Blessing, A. dan I. O. Gregory. 2010. Effect of processing on the proximate composition of the dehulled and undehulled mungbean (Vigna radiate (L.) Wilczek) flours. Pakistan Journal of Nutrition, 9 (10): 1006-1016.

Budijanto, S., A.B. Sitanggang, dan W. Murdiati. 2011. Karakterisasi sifat 
fisiko-kimia dan fungsional isolat protein biji kecipir (Psophocarpus tetragonolobus L.). Jurnal Teknologi dan Industri Pangan 22 (2):130-13

Collado L.S. dan H. Corke. 1999. Heat moisture treatment effects of sweetpotato starches differing in amylose content. J Food Chem 65: 339346.

Dibofori, A. N., P. N. Okoh dan A. O. Onigbinde. 1994. Effect of germination on the cyanide and oligosaccharide content of lima beans (Phaseolus lunatus). Food Chemistry 51: 133-136.

Elvira, N. 2018. Studi Sifat Kimia, Fungsional, dan Daya Cerna Protein Tepung Kecambah Kacang Tunggak (Vigna unguiculata (L.) Walp.) [skripsi]. Tidak dipublikasikan. Universitas Udayana. Badung.

Julita, A. N. 2012. Karakteristik Tepung dan Pati dari Ubi Jalar Cilembu dan Ubi Jalar Ungu Ayamurasaki [skripsi]. Tidak dipublikasikan. Institut Pertanian Bogor. Bogor.

Kavitha, S. dan R. Parimalavalli. 2014. Effect of processing methods on proximate composition of cereal and legume flours. J Hum Nutr Food Science 2 (6): 1051.

Lin M. Y., Humbert E. S., dan Soluski F.W. 1974. Certain Functional Properties of Sunflower Meal Products. J Food Sci 39: 368- 373Pranoto HS, Mugnisjah WQ, Murniati E. 1990. Biologi Benih. Bogor: Pusat Antar Universitas, IPB.

Lombu, W. K., N. W. Wisaniyasa, dan A.A.I.S. Wiadnyani. 2018. Perbedaan karakteristik kimia dan daya cerna pati tepung jagung dan tepung kecambah jagung (Zea mays L.). Jurnal ITEPA 7: 43-51.

Lopez, O.P. dan Escobedo, M. 1989. Germination of amaranth seeds: effect on nutrient composition and color. Journal of Food Science 54: 761-762.

Mares, L. F. d. M., M. C. Passos, dan C. C. Menezes. 2017. Interference of germination tine on chemical composition and antioxidant capacity of white sesame (Sesamum Indicum). Food Science and Technology.

Ocheme, O. B., E.O. Adedeji, G. Lawal, dan U. M. Zakari. 2015. Effect of germination on functional properties and degree of starch gelatinization of sorghum flour. Journal of Food Research 4 (2): 159-165.

Oluwalana, I. B. 2014. Comparative effects of sprouting on proximate, mineral composition and functional properties of white and yellow sweet maize (Zea Mays Var Saccharata). Journal of Emerging Trends in Engineering and Applied Science (JETEAS) 5(7): 111115.

Osman, M. A. 2007. Effect of different processing methods on nutrient composition, antinutrional factors, and in vitro protein digestibility of dolichos lablab bean (Lablab purpuresus (L) Sweet). Pakistan Journal of Nutrition 6(4): 299-303.

Rumiyati, A. James, dan V. Jayasena. 2012. Effect of germination on the nutrional and protein profile of australian sweet lupin (Lupinus angustifolius L.). Food and Nutrition Science 3: 621-626.

Steel, R. G. dan J. H. Torrie. 1995. Prinsip dan Prosedur Statistika. Diterjemahkan 
oleh Bambang Sumantri. Gramedia Pustaka Utama. Jakarta.

Sudarmadji S., B. Haryono, dan Suhardi. 1997. Prosedur Analisa untuk Bahan Makanan dan Pertanian. Liberty. Yogyakarta.

Usman, I. Rahim, dan A. A. Ambar. 2013. Analisis pertumbuhan dan produksi kacang koro pedang (Canavalia ensiformis) pada berbagai konsentrasi pupuk organic cair dan pemangkasan. Jurnal Galung Tropika 2 (2): 85-96.

Utomo, J. S. dan S. S. Antarlina. 1998. Teknologi pengolahan dan produkproduk kacang tunggak. Monograf Balitkabi 3: 120-138.

Winarno, F. G. 1992. Kimia Pangan dan Gizi. Gramedia. Jakarta.

Wisaniyasa, N.W., K.Suter, Y. Marsono, dan I.N. Kencana Putra. 2015.Germination effect on functional properties and antitrypsin activities of pigeon Pea (Cajanus cajan (L.) Millsp.) sprout flour. Journal Food Science and Quality Management 43: 79-83.

Wisaniyasa, N.W. dan I.K. Suter. 2016. Kajian sifat fungsional dan kimia tepung kecambah kacang merah (Phaseolus vulgaris L.) dan aplikasinya menjadi flakes. Jurnal Media Ilmiah Teknologi Pangan. 3 (1) : 26-34.

Zayaz, J. F. 1997. Funcionality of Protein Food. Springer. Verlag Berlin Heidelberg. 